Berry, Edward Wilber

The physical conditions and age indicated by the flora of the alum bluff formation 


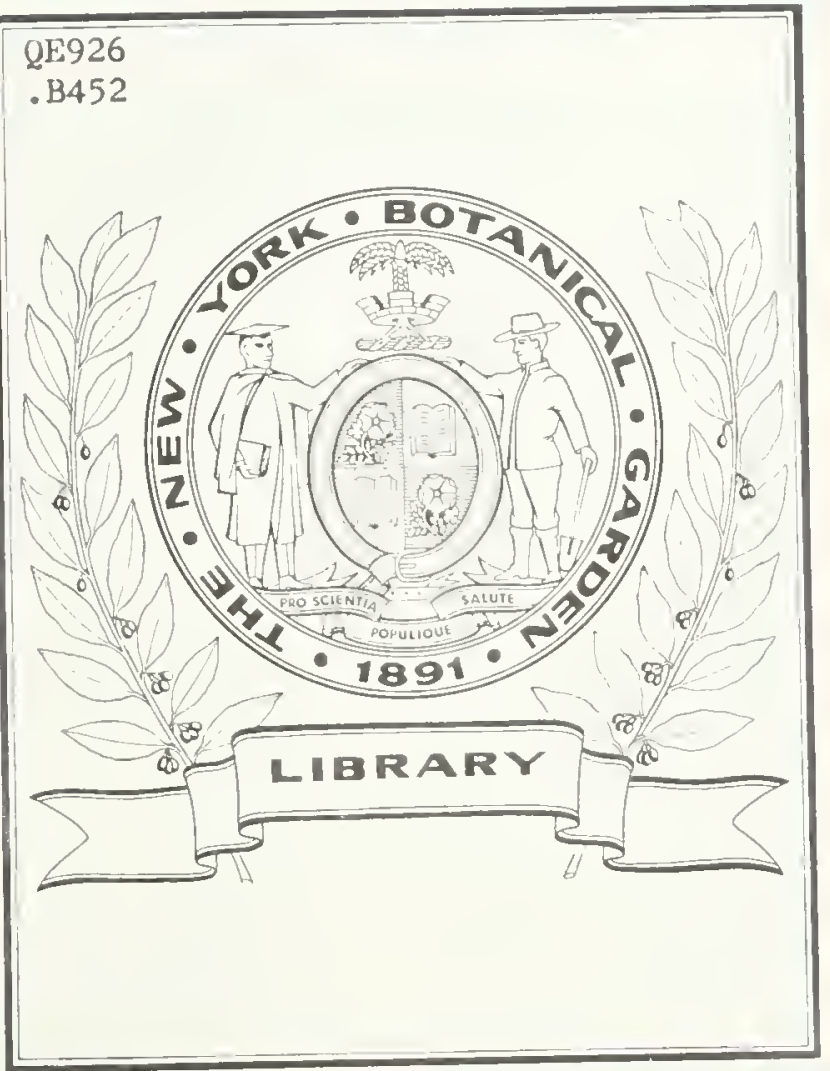






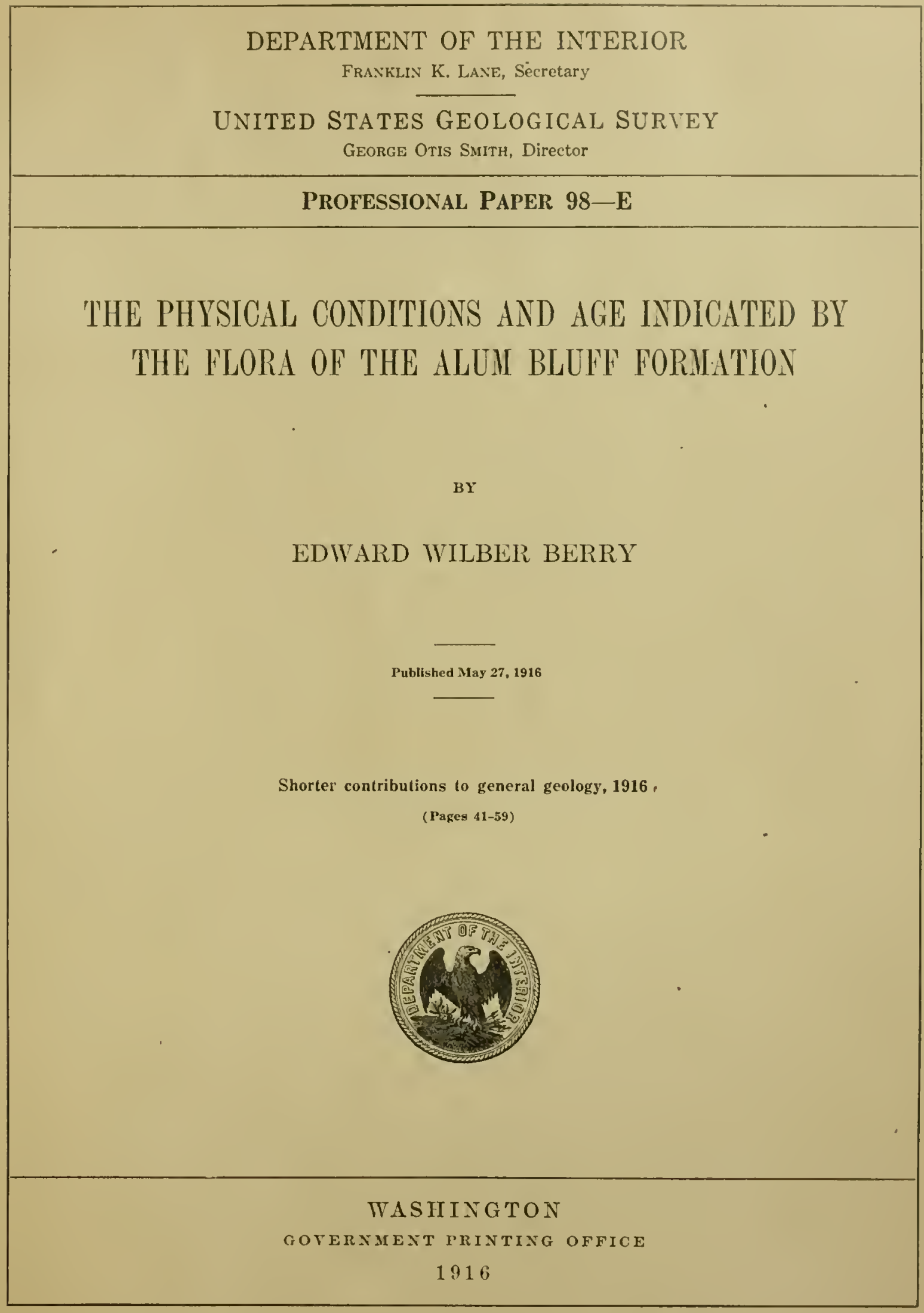



DEPARTMENT OF THE INTERIOR

Franklin K. Lane, Secretary

UNited States GEOLOGICAL SURVEY

George Otis Surth, Director

Professional Paper 98-E

\title{
THE PHYSICAL CONDITIONS AND AGE INDICATED BY THE FLORA OF THE ALUM BLERT FORILATIOS
}

\author{
BY \\ EDIVARD WILBER BERRY \\ Published May 27, 1916
}

Shorter contributions to general geology, 1916

(Pages 41-59)

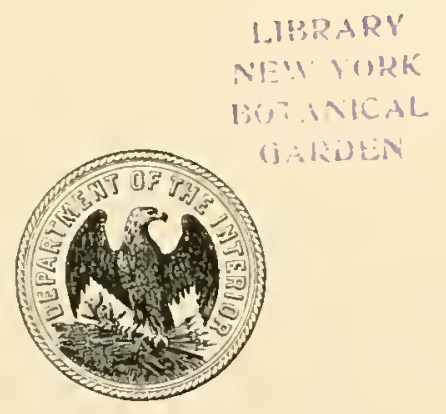

WASII I NGTON

GOVERNMEXT TRINTING OFFICF

1916 


\section{CONTENTS.}

Page.

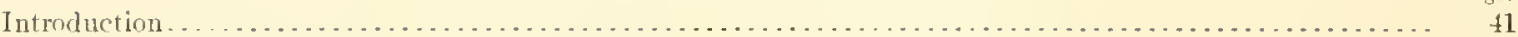

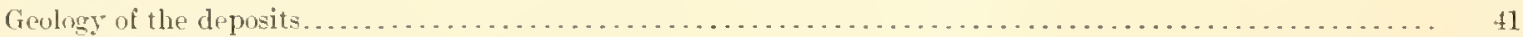

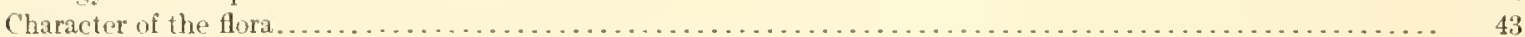

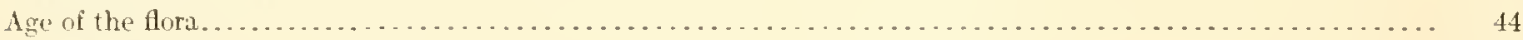

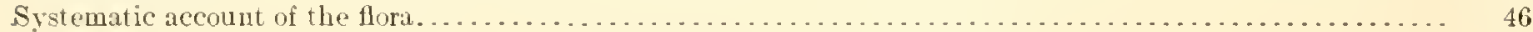

\section{ILLUSTRATIONS.}

Plate TII. A, Plant-bearing beds in the Hattiesburg clay near Raglan, Forrest County, Miss.; $B$, Plant-bearing beds at the type locality of the Alum Bluff formation, Alum Bluff, Apalachicola River, Liberty

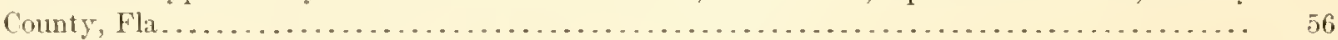

VII-X. Fossil plants from the Alum Bluff formation at Alum Bluff, Fla.................... $57-59$

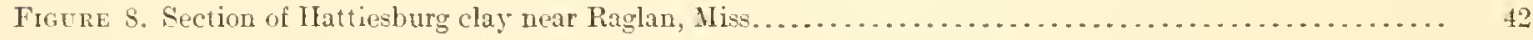




\title{
THE PHYSICAL CONDITIONS AND AGE INDICATED BY THE FLORA OF THE ALUM BLUFF FORMATION.
}

\author{
By Edwarn Wilber Berry.
}

\section{INTRODLCTION.}

The present paper has for its purpose the deseription of a small flora collected from the Alum Bluff formation, representing a horizon hitherto unrepresented paleobotanieally in southeastern North America, and the diseussion of the bearing of this ftora on the physical conditions of deposition and the probable age of the deposits.

\section{GEOLOGY OF THE DEPOSITS.}

The Alum Bluff formation was named from the bluff of that name on the east bank of the Apalachicola Rirer, about 25 miles below Chattahoochee or Rirer Jumetion, in Liberty County, Fla. (See Pl. vil, B, p. 56.) It is, aceording to present knowledge, the uppermost formation of the Apalachicola group. It comprises three members, which, named in ascending order, are the Chipola marl member, the Oak Grove sand member, and the Shoal River marl member.

The Chipola marl, which is a thin yellowish elay marl at the base of the formation as defined by Matson and Clapp, earries a rery extensive and well-preserved marine fanna. It was named from Chipola River, in Calloun County, Fla. The Oak Grove sand, stratigraphically intermediate between the Chipola and Shoal River, is a thin, highly fossiliferous gray or greenish fine sand named from Oak Grove, on Íellow hiver, and not represented by a lithologic unit at Alum Bluff. 'The Shoal River marl, the highest known fossiliferous member

\footnotetext{
I 'The geology of this region is fully diseussed in the following publications:

Matson, G. C., and Clapp, F. G., A preliminary report on the geology of Florida: Florida Geol. Survey Secomd Inn. Lept., pp. 21-173, 1909.

Vuughan, T. W. . I contribution to the reolo ic hist ory of the Floridian Plateau: Carnegie Inst. Washington Pub. 133, pp. 99-155, 1910; sce also U. S. Feol. Survey I'rof. Paper $71, \mathrm{pp} .741-715,1912$.
}

of the formation, is a thin series of interbedded greenish sands and marls overlying the Oak Grove sand. It was named from Slioal River, in western Florila, and is not represented by a lithologie unit at Alum Bluff.

The following section was taken at the point where the fossil plants were colleeted, near the lower end of the bluff and in the immediate ricinity of the section measured by Dall. ${ }^{2}$ It is deemed worthy of reproduction beeanse it differs in eertain particulars from Dall's sertion. Still other seetions from different parts of the bluff are given by Sellards and Gunter. ${ }^{3}$

$$
\text { Section at Llum Bluff, Fla. }
$$

Pleistoeene (?):

Fext.

Light-colored ferruginous, rather louse sands. g

Ilard reddish clay.................... 2

Tariegated redrish and yellowish ferruginous sands......................... (i)

Iiocene:

Choetawhatehee marl:

Dark-gray pyritiferousclay, more or lessearlonaceous but scarcely meriting the term lignitic given to it by Langlon, as no lignite or plant fossils were observed in it. Traces of invertebrate fossils, for the most part undeterminable, were olserved in places. The prritiferous character of the clay gives it an alum-like taste, whichaccounts for the name of the l, ufi. Approximate thickness. Bluish (when unweatlrered) fossiliferous clayunarl of irregular thickness, earrying $\mathrm{M}$ /inia congesta, Ecphora quartricostata, Tumitella ruriabilis, and other species; mueh oxidized in its upper portion, in which the iossils are represented by poor casts, owing to the solution of the shell substauce ..... 15-30 Erosion unconformity.

21)all, II. 1I., and Stanley-Brown, J., Cenozoic geolowy oloug the Apalachicola River: Geol. Soc. America Bull, vol. 5. p. 15\%, 1494

Sellards, F. II., and Cunter, Merman, Florida Geol. Survey Second Ann. Rept., pp. 275, 27i, 1909. 
Oligacene:

Alum Bluff formation:

Cross-bedded laminated sands with clay lam ince and thin listorterl ray lenses of small rxtent. The sanuls are lucally thicker brdderl and argillaceous, especially in the npper part, where they are in places packed with the distorterl detacherl rays of a Saballike palm. In the lowror part thes are more evenly bedrlat and liss argillaceous, being composed largely of a somew hat enarser gray iron-stained sand with vegetable matter aggregated in definite but not everywhere lorizontal layers. IIere and there are thin iron crusts, and some of the more argillaceous laminae are bluish in color. Leaf impressions are much more abmulant and varied in these lower layers. The thicknoss is variable, the maximum observer being ahout. .

Gray calcareous compact massive, in places slightly phosphatic sand, somewhat fossiliferous; thickness about...............

Chipola marl member: Compact ferruginous, ahundantly fossiliferous argillaceons sand carryiug Orthaulax and other elaracteristic Oligrocene invertebrates; thickness exposed........................ $3-$ most Oligocene or hasal Miocene flori, practically the only one known in North Imerica.

In Fomest Comnty, Miss., in beds included by L. C. Johnson in the ITatticshmg clay (see Pl. vil, 1, p. 56), I discorered in the summer of 1910 a small flora that appears to be synchronous witl that at Almm Bhuff. The exact loeality is on the south side of the New Orleans, Mobile \& Chieago Raiload, 1 mile east of Raglan, and the onterop shows the following section (see alsu fig. S):

$$
\text { Section neur Ruglan, Miss. }
$$

a

2. Light sandy clay .................... 1-2

3. Compact argillacesus lignite or brown lignitic

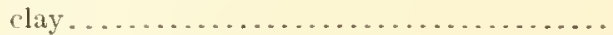
Uneonformity (local?).

4. Yellowish or gray argillaceous fine sand or sandy elay, grarling into underlying heds...........

12 5. Similar materials of greenish color, weathering yellowish, irregularly belded and carrying large numbers of poorly preserved plant remaius, mostly palm rays; grades into underlying leds; thiekness about ............... 1. Fellowish or greenish much-jointed santy clay..

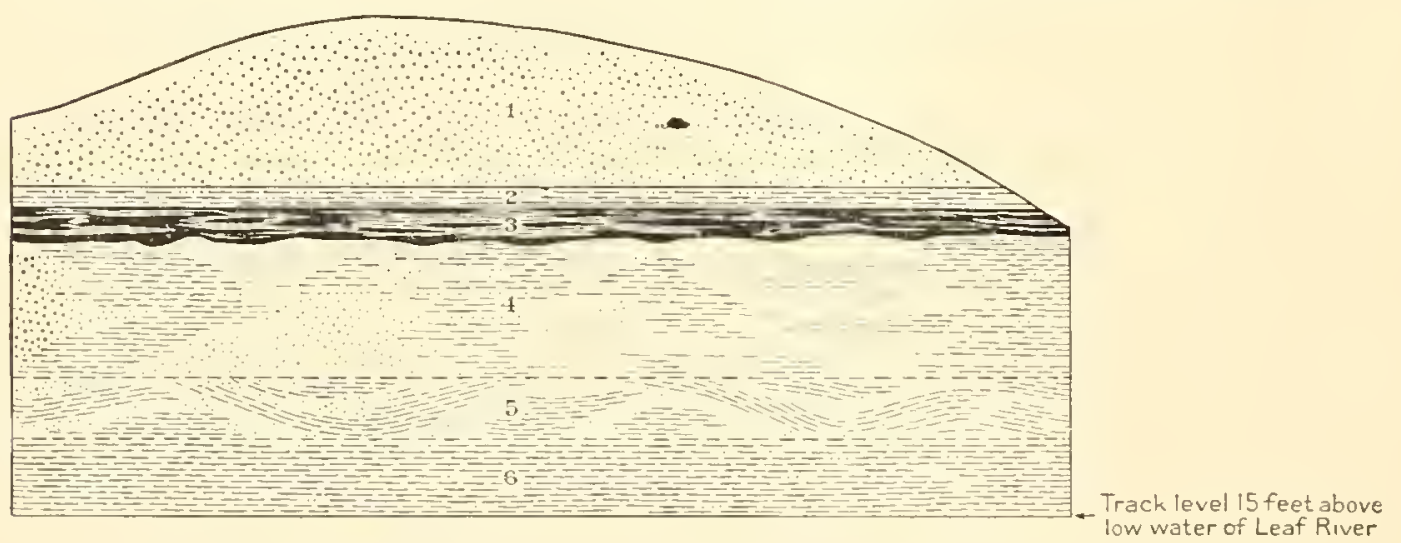

FIGURE 8.-Section of IIattiesburg clay near Raglan, Miss. Numbers correspond to those given in the section in the text.

Alum Bluff is a most interesting spot to the physiographer, beeause of the striking contrast in topograplyy between the east and west banks of the river; to the geologist, because it is a rassic loeality for the so-called Old Miocene and represents also the oldest known southern outrop of the Chesapeake Miorenc: and to the botanist, beeause in the wooded and damp ravines along the bluff are to be found two isolated gymmosperms, both relies of brgone floris, Taxus foridana. Nuttall and Tumion taxifolizem. (Arnott) Greene. Alum Bluff is of particular interest to the palcohotanist, because it furnishes a representation of an upper-
The plants in the sands at both the localities mentioned above are few and rery friable. Collections could not be made in the usual way, and as my improvised method proved rery satisfactory it is worth describing. A small excavation in the loose, slumped sand was lined with a large piece of bulap. This was pirtly filled with plaster. While the plaster wibs still soft the sandy specimen was placed in it, the face of the specimen being left about an the lerel of the plaster. After the plaster had set the face was thickly rovered with cotton, over which the free ends of the burling were wripped and tied firmly. Erery speci. 
men treated in this way, some of which were 10 inches in diameter, survived the rough handling on the rivel boat and the froight transportation to Baltimore.

Fossil. plants from Alum Bluff have been mentioned by Langdon. ${ }^{1}$ Foerste, ${ }^{2}$ and Dall. ${ }^{3}$ A fow fragments of Sabalites were collected by Dall, but no srstematic collections were mand until I risited this outcope in $1910 \mathrm{in}$ company with E. H. Sellards, State geologist of Florida.

\section{CHARACTER OF THE FLORA.}

The flora is limited to 13 described species, although fragments of other specics are present, and I ohserved but did not succed in collecting a palmately reined Ficus, leaves of Gymincta or Xanthoxylum, and pods resembling those of the existing Gileditsia aquatica Marsh.

The determined species comprise a spot fungus (Pestalozzites), a very aloundant fan palm (Sabalites), and 11 species of dicotyledons, including an elm, breadfruit, buckthorn, camphor, satinwood, ironwood, and persimmon. There are 11 genera in 9 families and 8 orders. These families are the elm (Utmacex), mulberry (Moracex), pisonia (Nyetaginacex), senna (Cresalpiniacer), rue (Rutacco), buckthorn (Rhamnacer), laurel (Lauracex), sapodilla (Sapotaceæ), and ebony (Ehcnacer). The familics Lauracea and Sapotacex are each represented by two species; the remaining seren families have each a single species. By far the most abundant form is the palm, broken stipes and detached rays of which are thickly crowded in the sands in places. Four of the plants are ordinarily considered strictly tropical-the breadfruit (Artocarpus), blasiletto (Cesalpinia), Nectandra, and satinwood (Fagara). The genera Pisonia and Cimnamomum are commonly considered tropical, but Pisonia reaches the keys of southern Florida in the cxisting flora and the camphor trce (Cinnamomum) ranges northward to southern Japan and to the rain forests of southwestern China, while Cinnamomum camplora Linne is harly in eultivation around Tallahassec, Fla., and is

1 I angdon, D. W., Some Florida Miocene: Am. Jour. Sci, 3d ser, vol. 38, p. 322, 1559: Geology of the Coastal l'lain of $\Lambda$ labama, p. 373, 1 594 , 2 Foerste, A. F., Studies on the Chipola Niocene of Bainbridge, Fa.

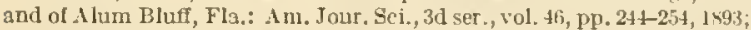
Fossil palmettos in Florida: Bot. Gaz., vol, 19, p. 37, 1594.

${ }^{3}$ Dall, W. H., and Stanley-Brown, Joseph, Cennzoic geology along the Apalichicola Rirer: Geol. Soc. America Bull., vol. 5, pp. 14i-170, I 149 . not uncommon as an escape from cultiration in woods and thickets throughout peninsulal Florida, being freely soeded by birds. In fact, soil, humidity, and the length of the growing scason secm to govern the extension of the tropical flora into the temperate zones to a much greater extent than actual extreme temperatures, the existing floras of both southeastern Asia and southeastem North America showing many parallel examples of such extensions.

The Sabalites is represented in the existing flora by the genus Sabal Arlanson, which is now confined to America. It consists of eight roastal or stream-border shmus and trees, five of which are confincel to the $\mathbb{W}^{*}$ est Indies, Mexico, and Venezuela; onc is confined to peninsular Florida, and two range northward along the Atlantic coast to the Carolinas.

The large mass of frayed and tangled rays and stipes of Sabalites in a matrix of sandy allurium both at Raglan, Miss., and Alum Bluff, Fla., suggest that at the time these deposits were laid down the shores were low and were densely elothed with palmetto "swamps" or brakes.

The gemus Ulmus, although it has tropical atlies, is in the existing flora a strictly northtemperate form having about 16 widely distributed species.

The family Rhamnacex is mostly tropieal, but sereral of the genera extend into the Temperate Zone, and Rhamnus, in particular, is mostly extratropical in the North Temperate Zone. There are about 75 existing species, and of the dozen North American forms several range northward to Canada and British America and only 1 ranges as far south as Florida.

The genus Bumclia has about a score or more of existing species, langing from Brazil northwarl through Central America and the West Indies to the Uniterl States, where two species are found as far north as Virginia and Illinois.

The genus Diospyros belongs to a large family that is mostly tropical in its distribution. Of the more than 200 existing species our common Diospyros virqiniane Linne is found as far north as southern New York and New England. The genus is representerl in southern Europe, and there are sereral species in eastern Asia. Moreover, of the 100 or more $^{\circ}$ 
fossil species that hare been deseribed many occur in associations that are obriously temperate in character.

To summarize the climatie conditions indicated by the flora, they are those of a tropical flora becoming replaced by a temperate flora, namely, subtropical or very warm temperate. These conditions are obriously different from those indieated by the Chipola marine fauna, which comprises over 400 known species, mostly Molhusea, and indicates a shallow sea (maximum depth not orer 20 fathoms) and, according to Vaughan, ${ }^{1}$ strictly tropical temperatures-that is, the bottom temperature of the water did not go below $70^{\circ} \mathrm{F}$. during the year.

As has already been indicated, the flora embraces a number of tropical types which, as is shown by the existing flora, are legitimately to he expected to extend more or less beyond the equatorial belt in areas where rainfall is abundant and where extremes of low temperature are absent. Assoriated with these are forms like Utmus, whose modern representatives are prevailingly north temperate but some of which extend into boreal regions. Still other of the Alum Bhuft forms, the Rhammus, Bumelia, and Diospyros, represent families which are mainly tropical in the existing flora but which as represented by these genera have extended over large areas of the warmer parts of the Temperate Zone.

It seems to me that among existing plant assemblages the Ahm Bluff flora represents three trpes of plant associations. One corresponds in a general way to the "low hammock" of present-day peninsular Florida, a type intermediate betreen the true hammock and the swamp type. A second plant assemblage indicated is that of the low-lying semiswamp palmetto-brake type, along with some forms of the sandy strand, such as Pisonia, Casalpinia, and Fagara. In other words, this flora would find a congenial habitat at the present time in the delta of Apalachicola River or almost anywhere along the coast of peninsular Florida. Although so much less extensire, the Alum Bluff flora is somewhat less tropical in its facies than the flora of the Wilcox group and decidedly less tropical than the floras of the Claiborne, Jackson, Vicksburg, or Catahoula. On the other hand, it has not nearly the temperate facies of the flora of the orerlying Chesapeake

'Vaughan, T. W., Carnegie 1nst. Washington Pub. 133, p. 156, 1910.
Miocene and also indicates much more humid conditions than the latter. This statement is based on the flora of the Calvert and a considaration of the abundant marine faunas of the Cakert, St. Marys, Yorktown, Duplin, Choctawhatchee, and . Iackson rille formations.

The Alum Bluff flora may be considered to be the result of a reversal of the history of the present flora of peninsular Florida. That is to say, the present flora represents primarily a temperate flora receiving additions from the Tropics, whereas the Alum Bluff flora represents an endemic tropical flora gradually becoming invaded by members of a temperate flora as a result of changing rlimatic conditions.

\section{AGE OF THE FLORA.}

The stratigraphic relations clearly inclieate that the Alum Bluff flora is younger than the Tickshurg Oligocene and older than the Chesapeake Miocene. The faumal and floral eridence is equally conelusice. Not a single Alum Bluff plant is common to the Oligocene (Vicksburg and Catahoula) floras of Mississippi, Lonisiana, and Texas nor to the Chesapeake Miocene floras, which are, however, smaller than those from the Oligocene. Moreorer, the facies of the Alum Bhuff flora is decidedly different from that of tho floras of any of these lorizons. There are no western United States or West Indian fossil floras for comparison, so that it remains to consicler the probable Emropean equivalents of the Alum Bluff.

Is the Ahm Bhufl flora is obriously younger than the alundant European floras of the Sannoisian (Lattorfian, Tongrian) and Stampian (Rupelian) and older than the exceedingly rich floras of the Helretian and Tortonian (Tindobonian), the only stages remaining are the Chattian (Kasselian), Aquitanian, and Burdigalian (Langhian, Mayencian).

The Chattian (Fuchs, 1894) is the lower Aquitanian of Munier Chalmas and De Lapparent (1593). It is considered the equiralent of the Kasselian and in the Paris Basin is represented, according to Lemome, by the meulières de Montmorencr. According to Haug its inrertebrate fauma is distinguished by the ahsence of Nliocene types.

The Aquitanian (Mayer, 1557) now has the narrow limits assigned by Dollfus (1906- 7 ). It marks the naximum regression of the Oligocene 
sea due to the clevation of the Pyrenees and the beginning of Alpinc orogenesis. Marine waters invaled the marginal consts in Aquitaine, the Gironde, and Provence, in southern Spain, in Italy, and at various points on the south side of the cistern Alps: but the great bulk of the Aquitmian sodiments are those of lalies. swamps, and lagoons, with lignites and abundant and widesproad mammals and plants. In Aquitaine the Tongrian is said to grade imperecptihly into the Aquitaninu both lithologically and faunally, and the latter passes into the Burdigalian in the sane grathal manner. The floras of the Aquitanian are likewise transitional in character between Oligocene and Miocene. The marine famnas, howerer, are said by Haug to contain only 4 per eent of Oligocene species and nuny Miocene species, but the foraminiferal genus 1epidocyclina passes without modification from the Chattian into the Aquitanian. The Aquitanian has long been considered the uppermost stage of the Oligocene, although many paleontologists have pointed out the resemblances between the upper Aquitinian floras and faunas and those of the Burdigalian. In recent years, under the leadership of Dollfus and other French students, the Aquitanian has been made the basal stage of the Miocene, although the question of its reference to the Oligocene or Miocene is rigorously disputed.

The Burligalian (Depéret, 1892) is closely related to the Aquitanian both faunally and florally. The marine faunas as well as the terrestrial floras are said to indieate a slight lowering of temperatures since Aquitanian time. Tectonic changes had caused the disappearance of the broad lakes of the Aquitanian, and the Burdigalian materials comprise marine sediments on the sonthern and western borders of the continent and a series of rirer, flood-plain, and swamp deposits (brown coal) in the region extending from France to Bohemia.

It can not be said that the Ahm Bluff flora offer's conclusire evidence for detailed correlation, as it is too small. All but two of the species are new and offer only indirect eridence. Of these new species the Llmus is rery similar to Utmus longifntia Unger, of the Aquitanian of Bohemia, Germany, Styria, and France, and the Sapotacites is most like Sapotacites (Chrysophyllum) sagorianum, from the Aquitanian of Sagror, in Carniola, described by Ettingshauson. The two species with an outside distribution, Cinnamomum scheuchzri and Diospyros brachysepala, havo both been identified in beds from a great rariety of horizons in Europe. Although many of these identifieations are of doubtful value, both species had a widv rancre, geouraphic as well as geologric. Tho original descriptions of both, by Alexander Braun, were based on material from the Tortonian of Oeningern in Barlen. The two species are typically OligoceneMiocene forms and both are common and charaeteristic in the Aquitanian and Burdigalian of Europe.

It is thus apparent that the $A 1 \mathrm{~m}$ Bhuff flora can be considered either Aquitanian or Burdigalian, with a slight preponderance of the evidence in favor of the Aquitanian. Maury ${ }^{-1}$ on the eridence of the molluscan fauna correlated the Chipola marl with the Aquitanian and considered the Oak Grove fauna, as well as that of the sands at Alum Bluff above the Chipola, as "transitional" between Aquitanian and Miocene. If subsequent paleozoologic studies corroborate Maury's work, there will be substintial agreement between the floral and faunal evidence.

If the Alum Bluff formation is of Aquitanian or Burdigalian age-and one or the other alternative seems certain-the more or less acarlemic question is raised whether it shall be classed as Oligocene or Miocene.

Since the proposal of the term Oligocene by Beyrich in 1554 many hase questioned its utility or ultimate surviral. Certainly there is but slight structural (diastrophic) evidence for placing the Oligocene-Niocene boundary in Europe between the Aquitanian and Burdigalian, and the marine faumas as well as the terrestrial floras and faunas show a gradual transition from the one stage to the other, so that the French paleontologrists will probably be followed in their contention that the Arujtanian should be placed in the Miocene.

In considering the American application of the term Oligocene, it may be noted that thero appears to have ben continuous and uninterrupted sedimentation in the Florida area from the deposition of the underlying Chat tahoochee formation into Alum Bluff time. There also seems to have boen a succession of minor carth movements during this period, and thero was a greater influx of terrigenous materials into

1 Maury, (․ (G., Bull, Am. I’aleontology No. 15, 1902 
the Alum Bluff sea than in to the Chat ahoochee sea, a change in sedimentary character more probably due to an inland riso of the land which accelerated erosion than to the shallowing of the sea.

It seems obrious that thr Alum Bluff formation as a whole is a predominantly shallowwater deposit of clays and sands amel that the Chipola, Oak Grove, and Shoal River members are faunal zones contained in successire lenticular beds in the clays or sands. The faunules of these zones are dosely related but show,

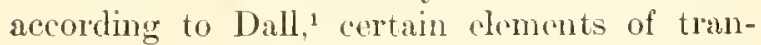
sition in the Oak Grove sand from the tropical Chipola fauma to one indicating a slight lowering of the temperature.

There is thus no structural (diastrophic) eridence for drawing the Oligocene-Miocene boundary between the Chattahoochec and Alum Bluff formations, nor is there any floral or faunal eridence for such a boundary. There is such a break between the Vicksburg and Apalachicola groups, and the Alum Bluff is separated by an erosion unconformity from the orerlying Choctawlatchee Miocene. It rests with invertebrate paleontology to determine whether or not the whole of the Apalachicola group shall be considered Miocene. Whaterer may be the final rerdiet, it remains true that the flora preserved at Alum Bluff records the last phase of sedimentation before the area emerged from the sea and that the most profound break in Tertiary sedimentation in the southeastern Lnited States, emphasized equally by epeirogenic, faumal, and floral changes, was at the end of Apalachicola timethat is, it is representel by the unconformity at the top of the Nlum Bluff formation.

\section{SYSTEMATIC ACCOUNT OF THE FLORA.}

\section{Class FUNGI.}

\section{Order MELANCONIALES.}

Family MELANCONIACEE.

Genus PESTALOzZITES Berry.

Pestalozzites sabalana Berry, n. sp.

Plate FIII, figure 3; I'late IX, figure 9.

Essential characters unknown. Found infesting the leares of Sabalites apalachicolensis Berry in consideruble abundance and causing

\footnotetext{
${ }^{1}$ Dall, W. H., Contributions to the Tertiary fauna of Florida: Wag-
} ner Free Inst. Sci. Trans, vol. 3, pt. 2, p p. 15it-15i5, 1903. the formation of leaf spots. These spots are of definite forn and recrular outline, small and circular at first, becoming larger with age and elongated paralled to the long axis of the ray, thus becoming elliptieal or lenticular in outline. Maxinum size observed. 1.5 centimeters in length and 0.5 contimeter in width. Arerage size, about 6 hy 2 millimeters. The appearance of the infested leares is well illustrated in the figures, and they are seareely to be distinguished from numerous loares of the existing serub palmettos, as for example, Serenoa serruluta (Michaux) IIooker, infested with the existing leaf-spot fungus Pestalozzia sp.

Occurrence: Iattiesburg clay, Raglan, Forrest County, Miss.; collected by E. WV. Berry. Alum Bluff formation, Alum Bluff, Liberty County, Fla.; collected by E. IT. Berry.

Collections: United States National Museum.

CIass ANGIOSPERM Æ.

Subclass MONOCOTYLEDONÆ.

Order ARECALES.

Family PALMACE压.

Genus SABALITES Saporta.

Sabalites apalachicolensis Berry, $n, s p$.

Plate VII, figures 1-5; I'late IX, figure 9.

Leaves of rariable size, the maximum diameter estimated (from collected material) at about 120 centimetors. Rachis large, linear, not enlarged at the base of the leaf, lenticular in cross section, with straight unarmed edges, continued for a short distance on the lower side of the leaf as a rapidly narrowed acumen which is only 3.5 eentimeters in length in the small specimen figured; abruptly rounded-truncate at the base of the leaf on the upper side, where an inconspicuous ligule is prosent. Rays numerous, 40 to 60 in number, carinate, linewrlanceolate in forn, expanding to their middle, and free for about the upper third of their length, more or less curred at the base. Maximum wilth observed about 4 centimeters; arerage about 2 centimeters. Midribs of rays not especially strong or prominent. Secondaries numerous, fine, longitudinal, parallel, largely immersed in the leaf substance, which must have been eoriaccous. No transverse reinlets observed.

This species has a recorded range along the coast of the Gulf of Mexico from Florida to 
rentral Mlississippi and is in plares abundant but averswhere fragmentary. In the ab-enero of fairty wall preserved sperimens showing the ruchis and sumon it is impossible to distinguish this form from the Wilcox species subu-

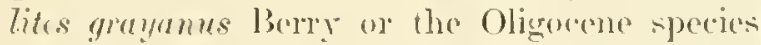
Sabalites visksburgensis Berry so that possitly the lattersperies, represented by incomplete mat terial, may be present in the Alum Bluft sinds, although I consider this extremely deubtful.

Sabalites grayanus differs from the present sprecies in the expanded uppere end of the rarlis, the longer and more gradnally narrowed acumen, and the more numerous rays, which are usually more conspicuously veined.

'The framents of rays which are so common in some of the deposits of the Vickshurg group and which are made the basis of Sabalites ricksburgensis are to be distinguished from $S$. a pulachicolensis chicfly by their much more prominent renation and longer and more slender arumen. The present species at its region of maximum occurence at Alum Bluff is harlly infested with a leaf-spot fungus which I have deseribed as Pestalozzites sabalana Berry, n. sp.

The foliage of palms is abundant and well distributed throughout the deposits of the Wilcox, (Jaiborne, Virkshurg, and Apalachicola groups, indicating the abundane of plants of this trpe in sontheastern North Ameriea during the Tertiary period. Few of these remains represent entire leares, and in many places only fragments of rays are preserved. PaIm leares are notoriously diffienlt of detremination, and the bulk of remains representing flabellate fan palms with an acumen are referred by American students to the genus Sabalites and by European students to Sabal. Two methods of speeifie differentiation are possible. Minor differenees and stratigraphic josition may be ignored, as in the case of the geographically and geologically wide-ranging Sabal major L'nger of Eurasia, or minor diflercnees that also represent differenees in geoloric age may have considerable weight in specifie difforentiation. The latter is the method that I love found most useful from both the biologie and the geologie viewpoint.

The extreme tropical climate of Tickshnrg and Catahoula time, which is reflected in the ahundant traces of palms fomed in deposits of Virkshurg or Catahomla age from Texas eastwarl, contimed thromgh the time of deposition

$$
3054.4^{\circ}-16-\ldots
$$

of the ('hipola mat monher of the Mum Bluff formation. Fortumately conditions were fartorable for petrification, and frigments of petrified palm trunks, many of them of Iarese size, are abundant thronghout the area underlain by the Tickshurg or Catahoula deposits. seren species of Palmoxilom lave berm described from these deposits. So far as I am aware no petrified palms have thus far been altained from the Ilum Bluff sands, hut palm foliage is very ahmolint in the leaf-bearing Iens at Alum Bluff. I have nerer seen so great an ahundance of stipes and rays of palms as oceur at this outcrop. In places whole layers consist of a mass of frayed and tangled rays in a matrix of sandy allurium. They are usually mudh macerated, and only here and there can larger fragments of leaves bre found. They are almost equally abundant in the similar materials cropping out near Raglan, Miss. This suggests the presence near the coast in late Ilum Bluff time of extensive palmet to swamps or brakes along the lower reaches of a sluggish river or estuary only a few feet abore mean water lerel-not flooded or true swamps, but subject to periodic orerflow.

Occurrence: Hatticsburg clay, Raglan, Forrest Comnty, Miss. (common; collected by E. W. Berry); and near Chicoria, on (hickasawhay River, Wayne County, Miss. (collected by E. IT. Berry). Alum Bluff formation, Alum Bluff, Liberty Countr, lila. (collected by E. II. B(rry), and Boynton Bluff, Choctawhatchee River, Fla. (collected by E. II. Sellards).

Collertions: Cuited States National Museum.

Subclass DICOTYLEDONA.

Order FAGALES.

Family ULMACEE.

Genus ULMUs Linnê.

Ulmus floridana Berry, n. sp.

I'late I.X. figures $\bar{j}-\bar{i}$.

Leaves of medium or smill size, ornte-lancoolite in general outline, with slightly inequilateral runeate rounded or subcordate base, and a gradually narrowed, somewhat extended areminate tip. Length from 4 to 7 centimeters. Maximum wilth, in the bisal half of the leaf, from 1.5 to 3 centimeters. Margins entire at tho extrome base, above which they are fincly and sharply doubly ser- 
rate, the terth increasing slightly in size distal. Potiole short and stont, about 2.5 millineters in length. Minrib of medium size, relatively thin and flexuous. Secondaries thin, 10 to 12, subopposite to altermate, in rather irregularly spaced pairs; they divelge from the midib at angles varging from abont $75^{\circ}$ near the base to $300^{\circ}$ near the tip, areraging about $50^{\circ}$; they pursue a rather straight raspedodrome course and nes thrir tips grive oft onc or two outwardly directed tertiaries, which run to the teeth or to the sinmses.

This well-marked species of Thmus appears to hare been common lluring Alum Bluft time and constitutes the oue strictly templerate element in the Alum Bluft flora. Amoner existing species it is most similar to Tlmus aluta Michaux, which ranges from western Iorida northward to Tirginia and from Texas to Illinois. Like $C$. alato, the forsil species was jrobably an inhabitant of rich alluvial swamp and stream horders, for it seems probable that the fossiliferous lens in the Nlum Bluft sands is the result of stream ation. Imong fossil speries, of which many have been deseribed, it hears more or less resemblance to a number of widely srattered forms, especially because the limits of rariation of the foliage among different species of I lmus are not. wide. The most similar fossil form is Utmus Tongifolia, theseribed by Lnger $^{\top}$ and subsequently recorded from the Aquitanian of Bohemia, Gelmany, Styria, and Flance, which is extremely close to the Imerican species.

The genus L'lmus may be distinguished from the allied genus (arpinus by the usmally more inequilateral leares and by the tertiaries to the matoinal sinnses.

Occurrence: ILattiesburg cla f, Raglan, Jorrest County, Miss. (colleetud by E. IV. Berry). Alum Bluff formation, Alum Bluft, Iiborty County, Fla. (collected b, E. TT. Berry).

Collection: United States National Museum.

\section{Order URTICALES.}

Family MORACE压

Genus ARTOCARPUS Förster.

Artocarpus lessigiana floridana Berry, n. var.

Plate $X$, figures $5-7$.

Leares of large size, rather smaller than the type, but very poorly preserved in the current-bodded sands. It least 25 centimeters in

1 Unger, Franz, Chloris protogæa, p. 101, pl. 26, fig. 5, $1 \$ 4 \overrightarrow{7}$. longth and about. 13 centimeters in maximum width, thus more narrowly oblong in weneral outline than the trpe. Pinnately s to 10 lobert; the lobes short, relatively broad and conical, acutely pointerl and diuected obliquely outward, separated by very narrow simuses. Mirlribstout. Lateral primaries stout, diverging from the milrib at angles of about $45^{\circ}$, one to each lobe, teminating in its tip). Secondaries alternating with the primaries, one to each sinus, the latter with the rharacteristic marginal hem. Trertiaries mostly obsolete. Ireolation quadrangular where secn. Texture coriaresous. There was evidently considerable variation in outline, for the basal portion of the leaf shown in figure 6 has a cuncate lase and must have had stromgly ascernding lobes.

This form is based on very fragmentary specimens from the flum Bluff sands. It may be distinguished from Artocarms lessigiana by its relatively narower form and its finer venation. The latter comes from the Wileos group, a much earlicr horizon, and has not been found in the intervening interval, represented by the Claiborne, Tarkson, Vicksburg, and Catahoula deposits. I have a feeling that the Alum Blutf material represents a new species, but I hesitate to set un a species on such frogmentary material, which is, however, the best obtamable by the most careful collecting.

Remains of Artocarpus have been found in Europe, Greenland, and the Cnited States. In this country we hare the Ialamie-Denrer type, which is considered the parent stock of the present rariety. This type and two other species are represonted in the late Wilcox of Louisiana and Arkinsas by excellent material. There is a Fort Lnion species and another Eocene form on the Pacifie coast. In Furope sereral species range from the Cipler Cretacoous to the Pliocene.

'There are about 40 existing species of Artocarpus, all enclemic in the southeastern Asiatic legion, ranging from Ceylon throughout Malaysia to China and represented by cultivated forms in all tropical countries. They apparently liek not become extinet in North America until the interral between the deposition of the Alum Bluff formation and the migration of the Clesapeake Miocene fauna into the Florida region, a migration indicating a lowering of 
temperatures entircly sufficient to explain the extinction of Artocarpus on the mainland, but not offering a satisfactory explanation of $\mathrm{its}$ failure to survive in more southern latitudes.

Occurrenes: Alum Bluff formation, Alum Blufl, Liberty County, Fir. (collected by E. IV. Berry).

Collection: United States National Museum. Order CHENOPODIALES.

Family NYCTAGINACEZ.

Genus PISONIA Linné.

Pisonia apalachicolensis Berry, n. sp.

Plate $\mathrm{X}$, figure 1.

Leaves of relatively large size for this genus, oborate in general outline, with a broad apex, which is erenly roumded or bluntly pointed, and a gractually narrowed, sharply cuneate base. Length about 5.75 centimeters; maximum width, abore the middle, about 2.4 centimeters. Margins entire. Texture coriaceous. Petiole short and stout, about 6 millimeters in length. Midrib stout lut inmersed in the thick leaf substance, curred. Secondaries entirely inmersed and obsolete.

The modern species of Pisonia are numerous; they oceur chiefly in the Tropies in both hemispheres and are largely coastal types. They are abundantly developerl in Central America and tropical South America, and several species occur in the West Indies and Antilles. About 15 fossil species have been described, the earliest recorded being from the Upper (retaceous of both America and Europe. The lower Eocene of southeastern North America has furnished two well-marked species, there is a species said to be represented by both leaves and fruit in the basal Eocene of the Rocky Momntain area, a fourth species occurs in the Claiborne group, and a filth has been found in the Jackson. Perhaps the most similar fossil form, based on both leaves and fruits, is Pisonia cocenica Ettingshausen, ${ }^{1}$ from the lignites of Haering, in Tyrol, which is upper Eocene or lower Oligocene in age, occurring also as early as the Lutetian of England.

Among existing species several are close to the present form. Pisonia longifolia Sargent, of the beaches and shores of lagoons from the

'Ettingshausen, Constantin, Die tertiäre Flora ron Hàring in Tirol, p. 43, pl. 11, figs. 1-22, 1853.
Filorida keys through the West Indies to Brazil, is rery similar to Pisonia apalarticolensis, though only about two-thirds as large.

Occurrences: Almm Bluff formation, Alum Bluff, Liberty County, Jila. (collected hy E. IV. Berry)

Collection: Lnited States National Museum.

Order ROSALES.

Family CASALPINIACE压。

Genus CESALPINIA Linne.

Casalpinia sellardsi Berry, n. sp.

Plate IX, firures 1, 2.

Leaflets small, sessile, inequilateral, elliptical in outline, 7.5 millimeters in length and 4.2 millimeters in greatest width. Apex broadly rounded. Base strongly inequilaterally truncated, one margin ascending and the opposite margin subauriculate. Midrib slender. Secondaries two or more, slender, ascending, camptodrome. Margins entire.

This species, which is obriously new, is clearly the leaf of some shrub or tree of the family Caesalpiniacere. Though only a few specimens were obserred, this ean not be considered as indicating scarcity, for the plant material at Alum Bluff is all rather meager and poorly preserved. It seems probable that the present species was a nember of the strand flora, the strand being the habitat preferred by a number of species of this genus in the modern tropical American flora.

The fossil species may be compared with a number of existing species, with which it shows a very close agreement. Among preriously described fossil species it is rery alose to what has been identified by Schenk ${ }^{2}$ is Crsalpinia townshendi Ileer, from the Stampian of Sieblos, originally described by Ileer ${ }^{3}$ from the Aquitanian and Tortonian of Switzerland and Baden and identified by Geyler from the Messinian of Sicily.

There is a very notable display of Mimosacere and Casalpinjucese in the flora of the Wilcox group, and these elements probahly continued to be prominent throughout the remainder of the Eocene and the Oligocene,

'schenk, August, in Zittel, K. A., Handluch der P'alaeontologie, Abth. 2, Palaeophytologie, p. 700, fig. 369 (4), 1×90.

Heer, Oswald, Flora tertiaria Helvetice, vol. 3. 4. 137, fiks. 24i-37, ]ธรั9. 
athough the record is much less completely preserved in the post-ITilcox sediments. The prescut species is probably but one of many related forms that inhabited southeastern North America during the deposition of the Alum Bluff formation. It is more inequilateral than any of the known Tertiary speeies from this general region, although it might perhaps be considered a descendant of Cossulpimites pinsonensis Berry, a somewhat smaller, less oblique, and more coriaceous form, from the sands of middle Wilcox age in Madison Countr, Tenn. It is named for Dr. E. II. Sellarels, State geologist of Florilla, who risited this celebrated locality with me and helpel collect the fossil plants.

Oceurrence: Num Bluff formation, Alum Bluff, Fla. (collected by E. W. Berry).

Collection: United States National Museum.

\section{Order GERANIALES.}

Family RUTACEE.

Genus FAGARA Linnê.

Fagara apalachicolensis Berry, n. sp.

Plate IX, figure 2.

Leares compound. Leaflets sessile, of medium size for this genus, elliptical in general outline, with a broadly rounded apex and a broally pointed base. Length about 3 centimeters; maximum width, abore the middle, about 1.75 centimeters. Margins entire. Texture coriaceous. Midrib stout, somewhat flexuous. Secondaries four or fire, subopposite to alternate pairs, irregularly spaced, direrging from the midrib at angles rarving from $35^{\circ}$ to $50^{\circ}$, rather straight in their courses, abruptly camptodrome close to the margins. Tertiaries thin, more or less inmersed, forming small quadrangular or polygonal moshes.

The genus Fagara, which contains more than 150 living species of shrubs and trees, is cosmopolitan in tropical and subtropical countries. $\Lambda$ few forms more properly referuble to Xanthoxylum range for considerable distances in the Temperate Zone, palticularly in southcastern North America. Fossil forms based on foliage are usually confused with the closely allied genus Xanthoxylum Linné. Leaflets referable to Fagara are not uneommon throughout our southern Tertialy deposits, sereral different forms from the Eocene and Oligocene haring been leseribed. The genus appears to have been especially prominent in the torrid floria of the Vickshurg group, and the leaflets are rery abundant in the dars of that age. The present species is clearly unlike any of these, being especially different in its broad apex and narrowed base, and might readily be confused with the small entire leares of some live oak. The scarcity of leaf remains in the Alum Bluff formation renders any remarks on the redative abundance of their lescribed florib without much significunce.

Occurrence: Alum Bluff formation, Alum Bluff, Liberty County, Fla. (collected by E. W. Berry), and Boynton Bluff, Choctawhatchee River, Fla. (collected by E. II. Sellards).

Collection: Uniterl States National Museum.

\section{Otder RHAMNALES.}

Family RHAMINACE正

Genus RHAMNUS Linné.

Rhamnus apalachicolensis Berry, n. sp.

Plate IX, figure 8

Leares rather large for this genus, broadly elliptical in general outline, with a broad and evenly rounded apex and base. Length about 8 centimeters; maximum width, in the middle part of the leaf, about 4.6 centimeters. Margins entire, evenly rounded. Texture subcoriaceons. Midrib stout. Secondaries stout, four or five alternate pairs, cliverging from the midrib at angles of about $55^{\circ}$ to $60^{\circ}$, curving upward almost immediately in a broad, sweeping curre, becoming subparallel with the lateral margins, along which they arch camptodromely. Tertiaries thin, closely set, subparallel, mostly pereurrent at right angles to the midrib.

This large leaf is distinet from the numerous fossil speries of Rhamnus previously deseribed, although it resembles a number of them more or less closely. The genus has about 60 existing speeies, widely distributed in nearly all tenperate and many tropical parts of the wordd and found on all the continents except Australia.

The genus Rhimnus is fairly prominent in Tertiary floras of southeastern North America, the Rhamnaces being also represented by forms of Zizyphus and Paliurus of tropical type. Six species from the Wilcox group have been described, but none are yet known from 
the Claiborne, Jackson, Vickshurg, of Catahoula.

Ocrurrence: Alum Bluff formation, Mum Bhuff, Liberty County. Fla. (collected by E. W. Berry).

Collection: Inited States National Museum. Order THYMELEALES.

Family LAURACEE.

Genus NECTANDRA Roland.

Neclandra apalachicolensis Berry, n. sp.

Ilate IX, figure 3

Leares oblong-ovate in general outline, broadest near the midlle and tapering to the bluntly pointed apex and bise. Length about $S$ centimeters; maximum width, halfway between the apex and the base, about 2.5 centimeters. Margins entire, erenly curved., Texture coriaceous. Miclrib stout. Secondaries about 10 subopposite pairs, diverging from the midrib at wide angles, about $60^{\circ}$, rather straight in their courses two-thirds of the distance to the margins, where they curve abruptly upward and form a succession of small camptodrome arches along the margins. 'Tertiaries obsolete.

The genus Nectandra has about 70 existing species confined to tropical and subtropical America, several of which are practically identical with this Alum Bluff species. There are numerous fossil species, the genus being well represented throughout the Eocene of southeastern North America, especially in the sediments of the Wileox group, from which at least fire speeies are known. It is represented in the Claiborne and Jackson lut has not yet been found in the Vicksburg or Catahoula. The present species is not particularly close to any of the deseribed fossil forms.

Occurrence: Alum Bluff formation, Alum Bluff, Liberty County, Fla. (collected by E. IT. Berry).

Collection: United States National Museum.

\section{Genus Cinnamomum Blume.}

Cinnamomum scheuchzeri Heer.

Plate $\mathrm{X}$, figure 4.

Cinnamomum scheuchzeri. IIeer, Flora tertiaria Helvelix, vol. 2, p. 85, pl. 91, figs. 4-22; pl. 92; pl. 93, figs. 1, 5, 1856.

This species was described by Alexander Bram from both calyx and leaves, obtained in the Tortonian of Oeningen, Baden. Typical ma- terinl is eommon in the ype area in both the Ayuitanian and the Burdigalian. Only the original description of lleere, which is aceompanied by ample figures, is ritod above, for sanguine students have fancied that they had fouml this species at all lorizons from the Lpper Cretaceous to the Pliocene, and at a very larese number of localities throughout the Northern Hemisphere. Some of these illentifications are undoubtedly correct, and the species certainly had a wide geographic and geologic range. Other illentifieations are unquestionably erroneous, hut it is impossible to sift the good from the had without access to the original material, and I have therefore not attempted to give the synonymy or lange.

The Alum Bluff material appears to be identical with a part of Heer's material from the type area, and it is also of the same age, so that $I$ hare no hesitation in identifying it with Heer's species. It denotes an ovate-lanceolate leaf, rather abruptly pointed at the extremities, the base being broaler than the apex. Length about 8 centimeters; maximum width, in the midule part of the leaf, 2.7 centimeters. Margins entire. Texture coriaceous. Midrib) stout: Lateral primaries one on each side, subopposite, suprabasilar, camptodrome. Secondaries thin, three or four camptodrone pairs in upper half of the leaf.

Occurrence: Alum Bluff formation, Alum Bluff, Liberty County, Fla. (collected hy E. W. Berry).

Collection: United States National Museum.

\section{Order EBENALES.}

Family SAPOTACE压.

Genus BUMELIA Swartz.

Bumelia apalachicolensis Berry, n. sp.

Plate IX, figure 4.

Leares oblung-oluorate in gener-l outline, with an erenly pounded apex and a narrowed cuncate base. Length about 4 centimeters; maximum wilth, above the middle of the leaf, about 1.9 centimeters. Margins entire, rather full. Texture coriaceous. Petiole short and stout, about 2.5 millimeters in length. Niulrit, stout, especially proximad, curved. Secondaries thin, numerous, 10 to 12 subopposite to alternate pairs, subparallel, at approximately regular intervals; they diverge from the midrib at angles of about $40^{\circ}$ and are camptodrome 
in the marginal region. Tertiaries immersed in the leaf substance.

In tho modern flora the genus Bumelia embraces about 20 species of shrubs and mostly small trees, confuned to the Western Ilemisphere, where they are distributed from the southern United States through the West Indies, Mexico, and Central Ameriea to Brazil. Some of the species range northward to Virginia and southerm Illinois. They inhahit for the most part the strand, sandy soil near the coast, ricer bottoms, and the borders of swamps. Fossil species of Bumelia are numerous and the genus was probably cosmopolitan during the Tertiary-it was certainly common in the European area. It has been continuously represented in southeastern North America since the Lpper Cretaceous. Four lower Eocene speeies from this area have heen described, one of which, Bumetia pseudotenax Berry, from the Wilcox group of northern Mississippi, is not unlike the Alum Bluff species but somewhat smaller and relaticely narrower. Other species are present in the deposits of the Claiborne and Vicksburg groups.

Compared with existing American species the present form is closer to the temperate than to the tropical species. It is intermediate between Bumelia tenax Willdenow and $B$. lanuginosa Persoon and may stand in an ancestral relationship to these modern forms. The former ranges along the eoast from Cape Canareral to North Carolina and the latter from northern Florida along the Gulf coast and up the Mississippi Valley to southern Illinois and is abundant and of its largest size in the rirer bottoms of eastern Texas.

Occurrence: Alum Bluff formation, Alum Bluff, Liberty County, Fla. (collected by E. WT. Berry).

Collection: United States National Museum.

Genus SAPOTACITES Ettingshausen.

Sapotacites spatulatus Berry, n. sp.

Plate $X$, figure 2 .

Leares of medium size, obovate or spatulate in general outline, with a broally rounded apex, from which it narrows gradually with nearly straight lateral margins to the sharply cuneate base. Length about 7 centimeters; maximum width in the upper part of the leaf, about 2.75 centimeters. Margins entire. Texture coriaceous. Petiolar portion missing. Mirlib stont but more or less immersed. Secondaries obsolete by immersion. Tertiaries shown in microseopic preparations to form in very close meshed areolation.

Sapotacites is it form genus for generically undifferentiated or undeterminable menbers of the fanily Sapotacex, and numerons species that range from the Upper Cretaceous through the Tertiary liave been described. It is possible to rofer many of these ancient species, such as the numerous forms in the flora of the Wileox group, to Bumelia, Mimusops, Sideroxylon, Chrysophyllum, and other allied genera. The present form is much like a number of existing species of Mimusops as well as some forms of Bumelia. The family is chiefly tropical and subtropical.

No fossil species are especially close to the present one, although it shows considerahle resemblance to Chrysophyllum sagorianum Ettingshausen, ${ }^{1}$ from the Aquitanian of Sagor, 'n Carniola.

Oceurrence: Alum Bluff formation, Alum Bluff, Liberty County, Fla. (colleeted by E. W. Beriy).

Collection: United States National Museum. Family EBENACEE.

\section{Genus DIOSPYROS Linné.}

\section{Diospyros brachysepala Alex. Braun.}

Plate I, figure 3.

Ihospyros brachyscpalu. Alex. Braun, Die Tertiär-Flora vin Öningen: Neues Jahrb., 1845, p. 170.

Liospyros brachysepala. Heer, Flora tertiaria Helvetia, vol. 3, p. 11, I'l. 102, figs. 1-14; pl. 153, fig. 39h, 1859. Diospyros brachysepala. Friedrich, Beiträge zur Kenntniss der Tertiartlora der Sachsen, pp. 63, 119, 126, 253, 255 , pl. 6, fig. 1, 1583.

Diospyros brachysepala. Ward, Types of the Laranie flora: U. S. Geol. Survey Bull. 37, p. 104, pl. 49, figs. $1,2,1887$.

This early described species has been recorded from a large number of American and Eurasian loealities ranging in age from basal Eocene to Pliocene. It is improbable that a single species existed for so long a period, and I have therefore reduced the synonymy of

1 Ettingshausen, Constantin, Die fossile Flora von Sagor in Krain, 1t. 2, p. 14, pl., 12, figs. 19-21, 1877 . 
this specios to a few representative citations. The species has been recolded by Lesquereux, Warl, and others from the lower Eorene of the loeky Mountain areas, as well as lyy Heer from West Greenland. I an not reptiulu that all these recoleds are correct, for IViospyeres brachysepula is typirally an Oligo"enc-lliocene form. It is found in the trpe area in both the Aquitanian and Burdigalian.

The slum Bluff leares, like most of the material referred to this species, are relatively small, about 5.5 centimeters in length and 2.8 centineters in maximum width, miclway between the apex and the base, which are about equally pointed, the general outline being al-

\footnotetext{
$1 \mathrm{~A}$ much more complete synonymy is given in my paper The lower Eocene floras of southeastern Forth America: U. S. Geol. Survey Prof. Paper $9 !$ (in press).
}

most elliptical. The midrih is stont and the secondaries thin, numbering six or seren subopposite to altertuate ("ampledromo patirs. The leares here described ande close to a number of examples figured by lleer from thr type locality, but are relatively slightly broader than some of the forms referment to this species by different atuthors. In sommo respects they atre very similar to Diospums lemerernsis Kinow101, ${ }^{2}$ from Landa (probably upper Miocene), in Fellowstone P'ark.

Oceurrenee: Alum Bluff formation, Alum Bluff, Liberty Councy, Flat. (collecterl by E. W. Berry).

Collection: [nited States National Musenm.

2 Knowlton, F. II., U. S. Geol. Surrey Mlon. 32, pt. 2, p. 751, pl. 95, figs. 5,6 ; pl. $9 t$, fig. 1, 1999. 
PLATES. 


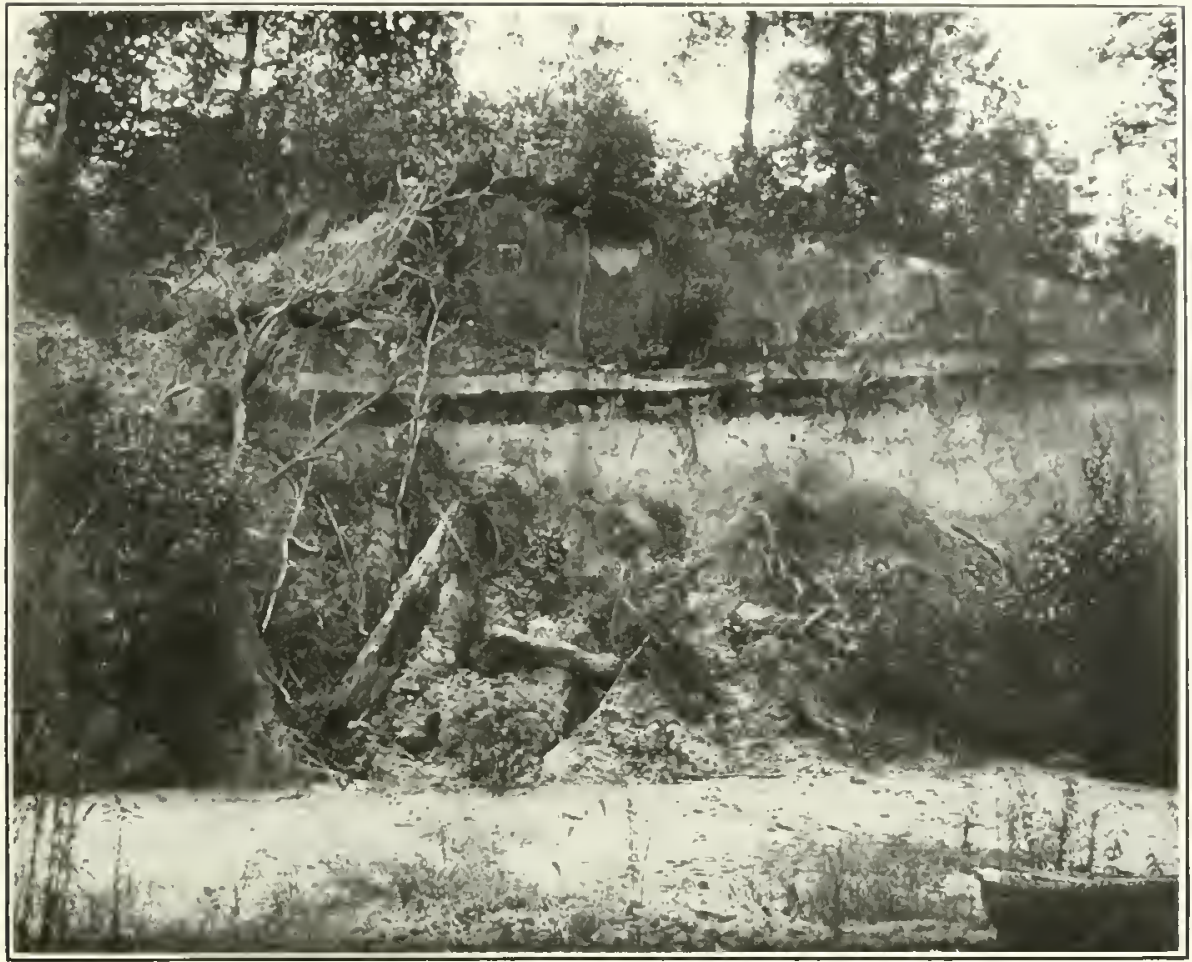

a. plant-bearing beds in the hattiesburg clay near raglan, FORREST COUNTY, MISS.

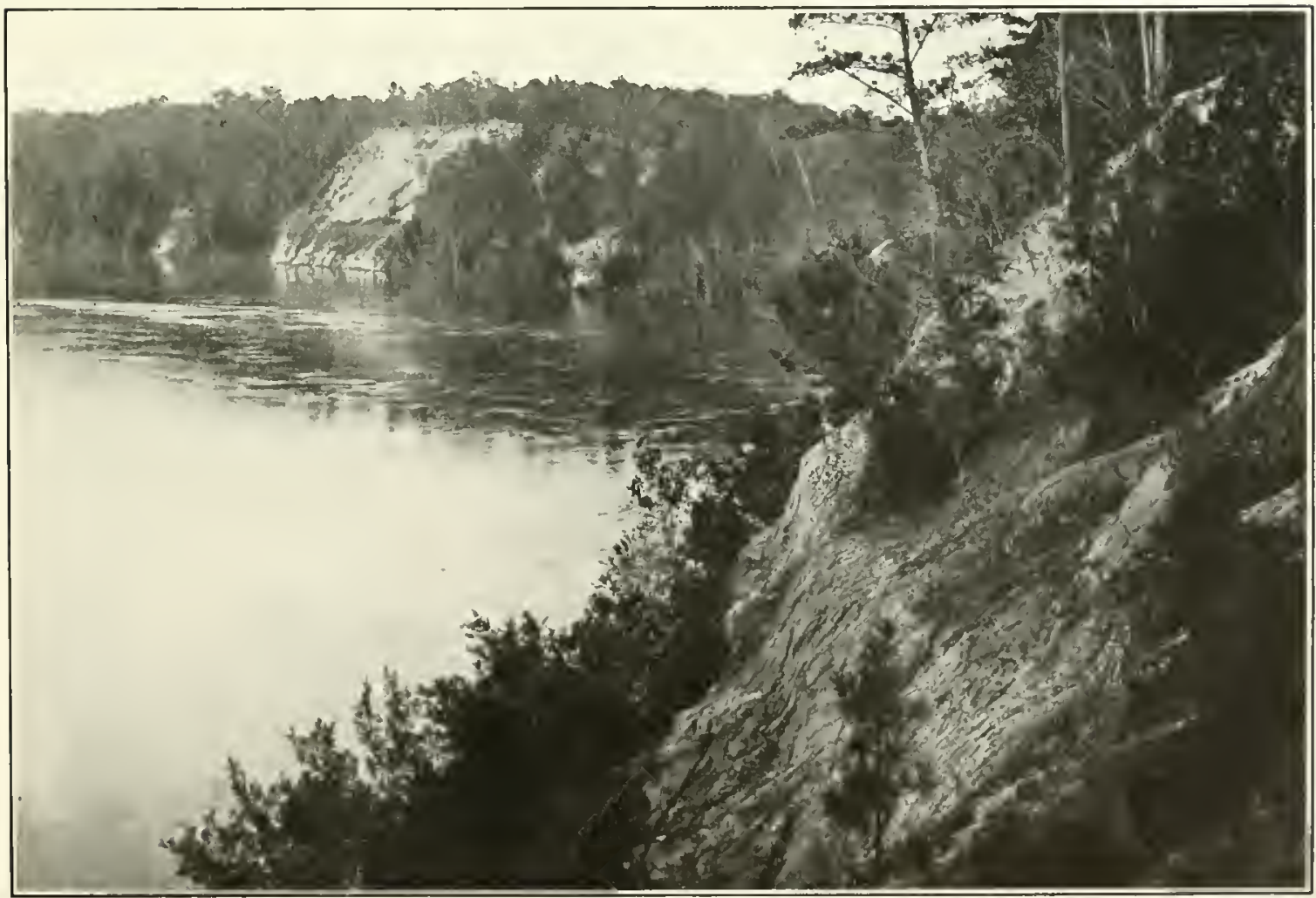

B. PLANT-BEARING BEDS AT THE TYPE LOCALITY OF THE ALUM BLUFF FORMATION, ALUM BLUFF, APALACHICOLA RIVER, LIBERTY COUNTY, FLA. 


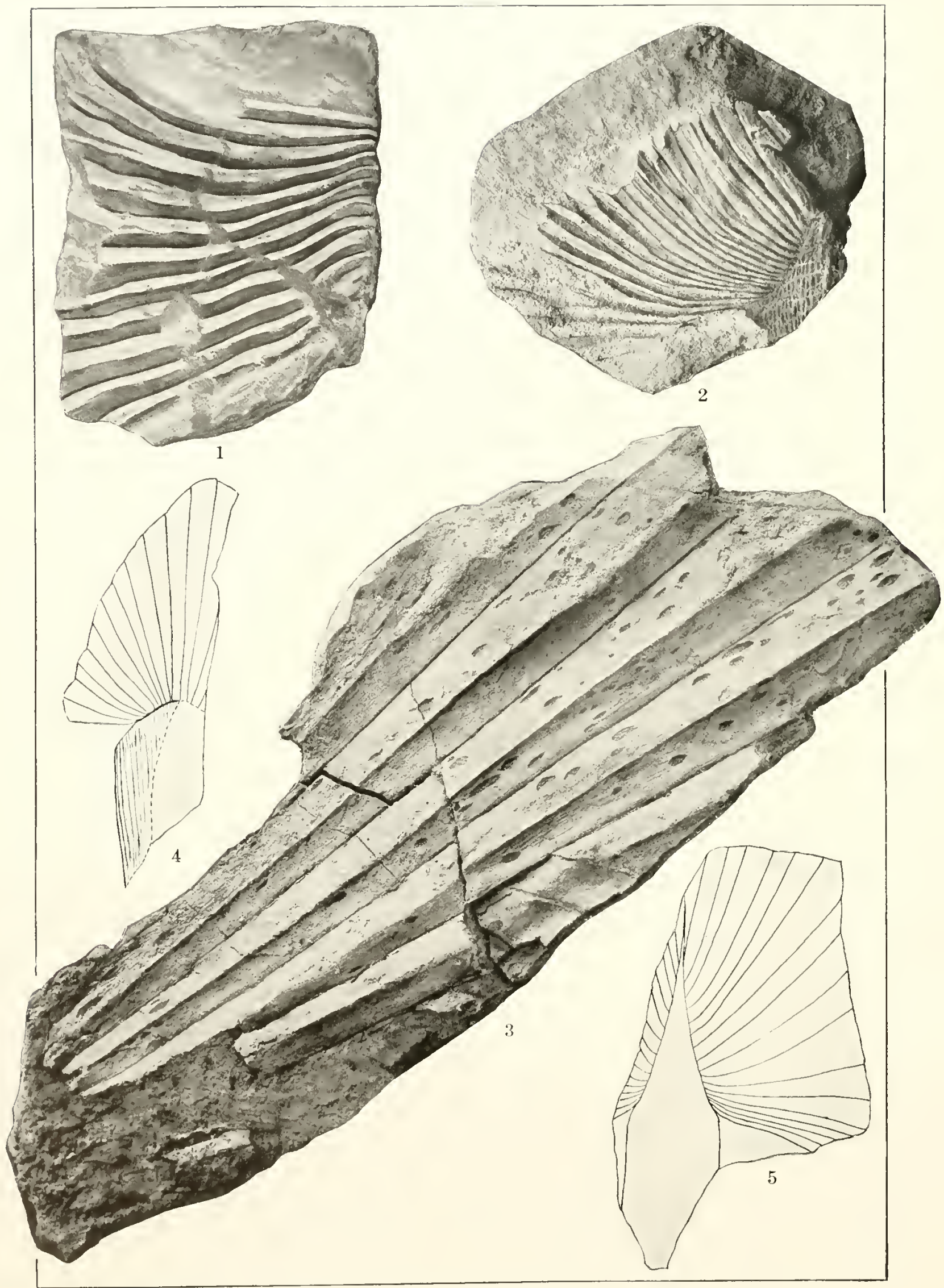

FOSSIL PLANTS FROM THE ALUM BLUFF FORMATION AT ALUM BLUFF, FLA. 


\section{PLATE VIII.}

Figures 1-5. Sabalites apalachicolonsis Berry, n. sp., from the Alum Bluff formation, Alum Bluff, Liberty County; Fla.

Figure, 2 and 5 show prolongation of the rachis as a midrib on the under side of the leat.

Figure 3 shows fragment of a leat infested with Pestalozzites sabalana lierry, n. sp.

Figure 4 shows the upper sirle of a leaf base and the termination of the rachis as a truncate ligule. 


\section{PLATE IX}

Figure 1. Crsalpinia sellardsi Berry, n. sp.

Figure la. The same, $\times \overline{\text { J. }}$.

Figure 2. Fagara a palachicolensis Berry, n. sp.

Firúre 3. Nectandra a palachicolensis Berry, u. sp.

Figure 4. Bumelia a palachicolensis Berry, n. sp.

Figures 5-7. Clmus floridana Ferry, n. sp.

Figure 8. Rhammus a palachicolensis Berry, n. sp.

Figure 9. Sabalites apalachicolensis Berry, n. sp. Portion of a very large leal infested with Pestalozztes sabalana Berry, n. sp. 
(9)

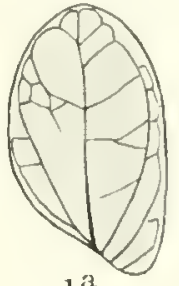

$1^{3}$
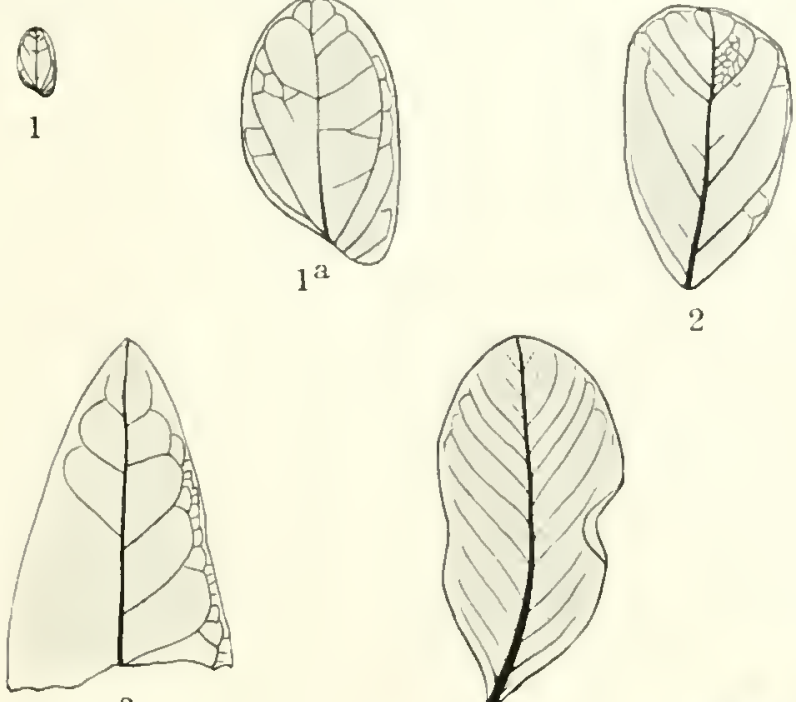

3

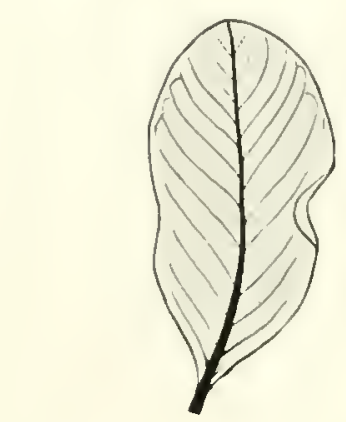

2
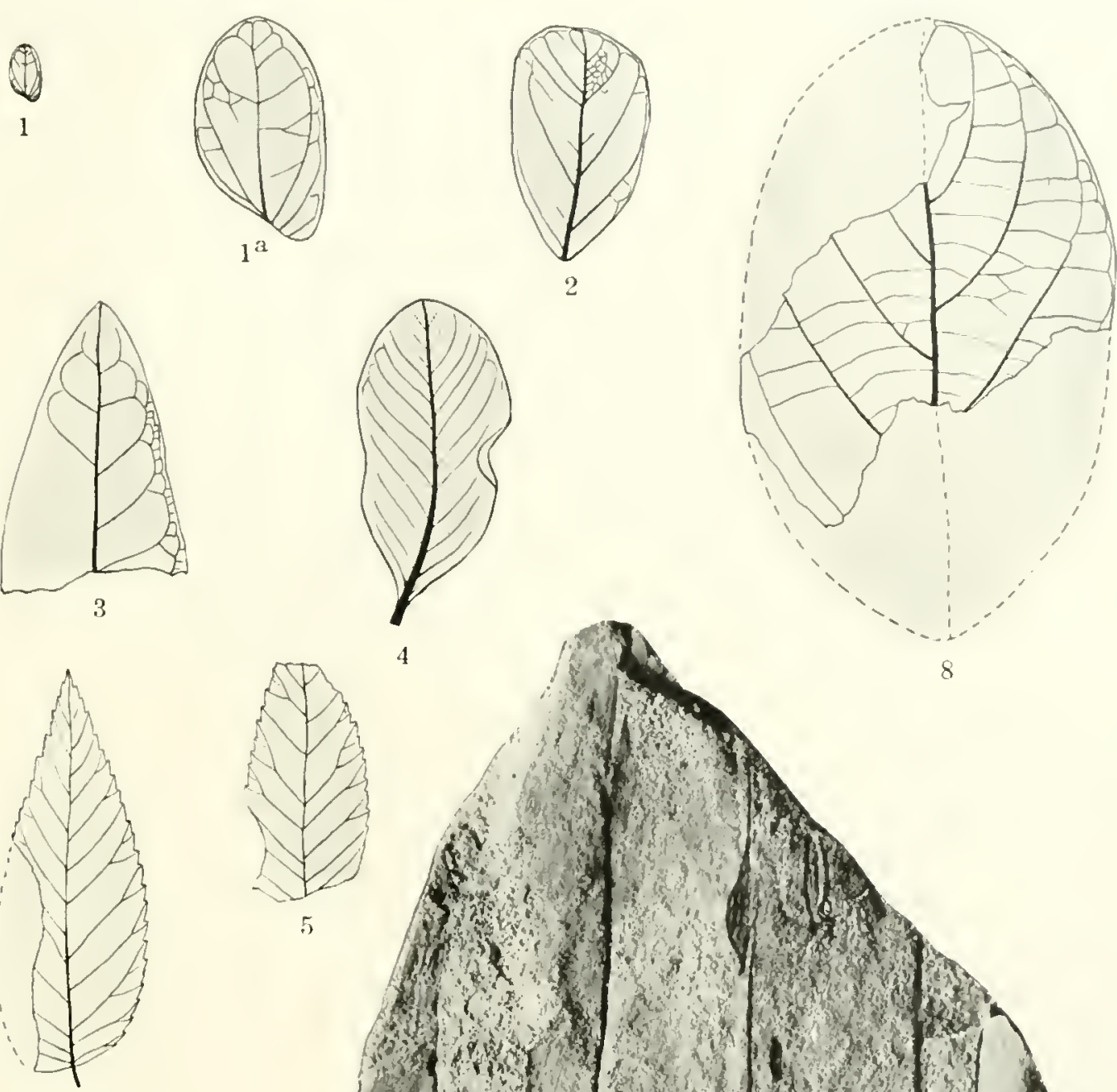

the

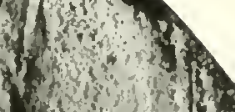

5

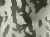

in:

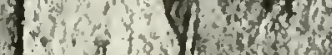

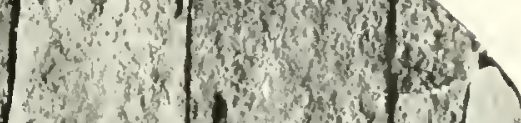

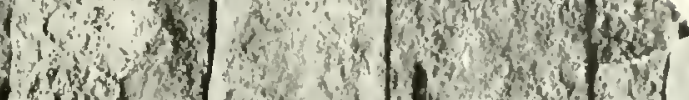

6

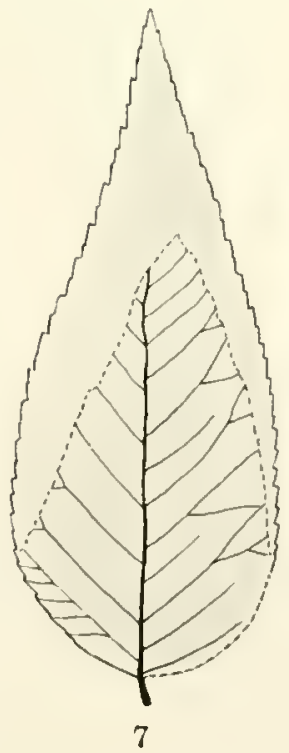

FOSSIL PLANTS FROM THE ALUM BLUFF FORMATION AT ALUM BLUFF, FLA. 


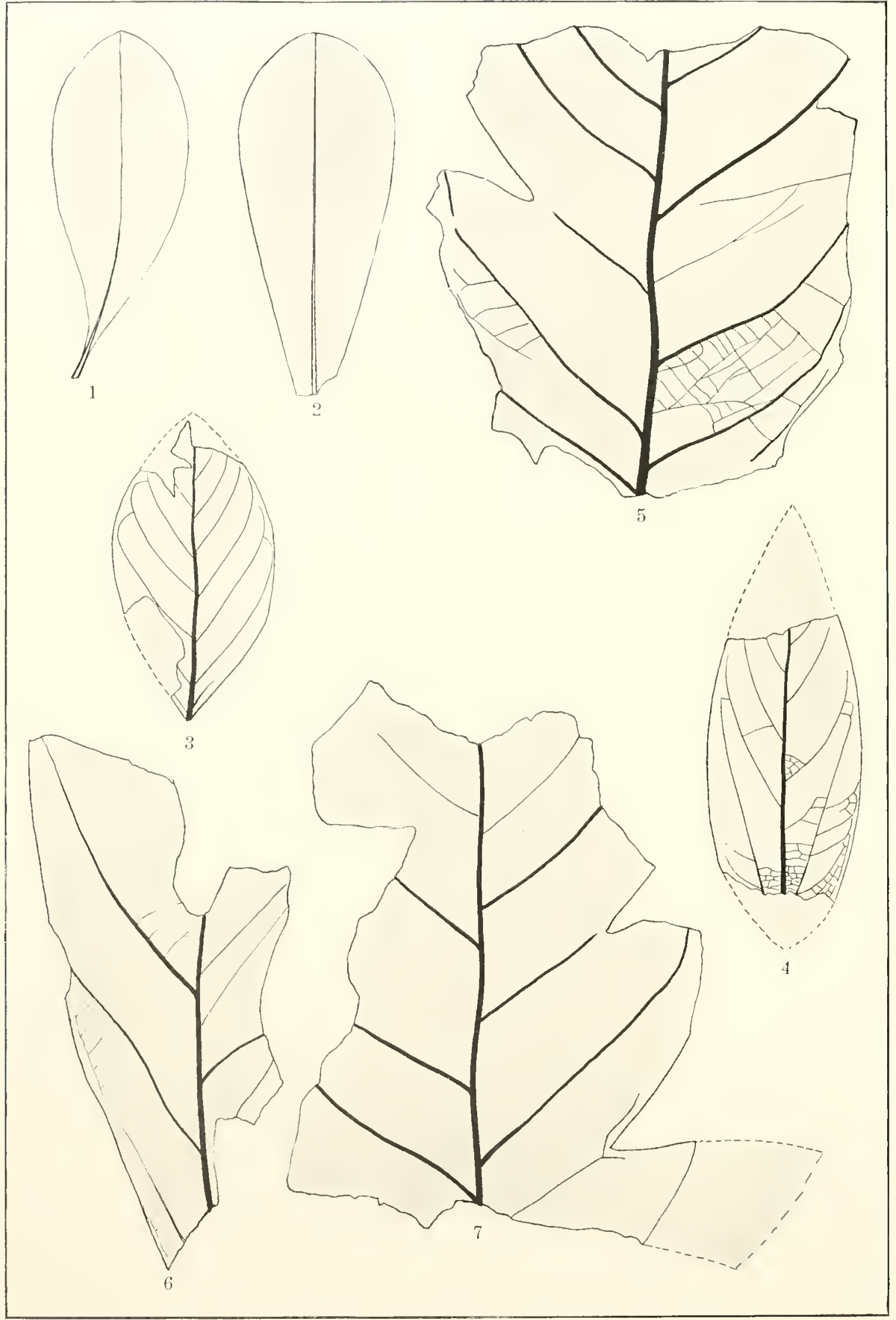

FOSSIL PLANTS FROM THE ALUM BLUFF FORMATION AT ALUM BLUFF, FLA. 
PLATE X.

Figure 1. Pisonia apaludiolonsis Berry, n. sp.

Frgure 2. Sapotacitos spatulatus Berry, n. sp.

Figure 3. Dis pyyos brachlsepala Mexanter Braun.

Figure 4. Cinnamomum schuthzeri Heer.

Figures 5-7. Artocarpus lossigiuna foridana Perry, n. var. 






